\title{
Private and professional life in autobiographies of Lithuanian women writers
}

\section{Summary}

The article analyzes women's autobiographies published in the most recent edition of Soviet Lithuanian writers' autobiography collection Tarybinių Lietuvos rašytoju auobiografijos (Autobiographies of Soviet Lithuanian writers, ed. Aldona Mickienė, Vol. I and II, 1989). Due to their professional careers, the Soviet Lithuanian female writers were part of the patriarchal and normative elite of the society, and thus acted as secondary characters of the said elite. In order to be treated as equals, the female writers, just like their male counterparts, primarily tried to present themselves as professionals, hence their autobiographies are dominated by public activities. On the other hand, the autobiography as a secondary genre, served well to express personal observations that were not considered fit for other, more official genres. The article aims to highlight the complex connection between personal traits of an individual and his or her living conditions the way it is reflected in autobiographies. It is then helpful to review the women's autobiographies written during that timeframe by relying on both, the research traditions of women autobiographies as well as the documentary studies of the Soviet society.

* Author contact information: solveiga@llti.lt 


\section{Keywords}

mid-twentieth century literature, women writers, writers' autobiography, women's autobiography, self-representation in autobiography

\section{Introductory remarks}

The relationship between "the truth" and "fiction" in the autobiography is one of the questions that has been discussed from the beginning of the research of this genre. As Shari Benstock claims, "autobiography reveals the impossibility of its own dream: what begins with the presumption of self-knowledge ends in the creation of a fiction that covers the premises of its construction" ${ }^{1}$. The reading of an autobiography provides one with an opportunity to trace how and to what extent the author creates his own (in this instance, her own) image based on external facts, how and to what extent the author teeters on the brink of "self-revelation", "testimony" (which is traditionally the prerogative of non-fiction) and "hiding", "re-creation of reality" (the prerogative of fiction).

Lithuanian researchers are faced with additional difficulties due to the lack of texts: when a written tradition is short, it is quite unlikely to find obscure, marginal autobiographies or other life narratives. Most of the Lithuanian authors, historians and writers examine the traumatic experience of the mid-twentieth century (Jūra Avižienytė, Tomas Balkelis, Dovilè Budrytė, Audronė Raškauskienè, and others) ${ }^{2}$. Although the number of memoirs and conversation books in Lithuanian literature is increasing, there are still very few "pure" autobiographies $^{3}$ written, especially by women. In recent years, researchers turned to oral interviews as their source of autobiographies ${ }^{4}$. As the result, the material chosen for this article was the last edition of professionally focused collection of Soviet Lithuanian writers' autobiographies which has been published under similar titles every decade (1957, 1967, 1977 and

1 Shari Benstok, Authorizing the Autobiographical. In: The Private Self: Theory and Practice of Women's Autobiographical Writings, ed. Shari Benstok, Routledge, London 1988, p. 11.

2 For further bibliography of autobiographic research of Eastern European as well as of Lithuanian scientists see: http://ejlw.eu/article/view/84/151.

3 According to Philippe Lejeune's description, autobiography is "a retrospective prose narrative produced by a real person concerning his own existence, focusing on his individual life, in particular on the development of his personality." Philippe Lejeune, The autobiographical contract. In: French Literary Theory Today: A Reader, ed. Tzvetan Todorov, Cambridge University Press, Cambridge 1982, p. 193, internet access: https:// english4321.files.wordpress.com/2010/08/philippe-lejeune-the-autobiographical-contract.pdf [accessed 4.07.2014].

4 For example, see: Adopting and Remembering the Soviet Reality: Life Stories of Lithuanian Women 1945-1970, ed. Dalia Leinartė, Rodopi, Amsterdam-New York 2010. 
$\left.1989^{5}\right)$. It is likely that in these texts written specifically for such autobiographic collections, a public identity (that of a female writer) is highlighted while a private identity (that of man, woman) is pushed into the background, especially since the Soviet society has always considered it to be of secondary importance.

\section{Autobiographies of Professionals}

One was considered to be a Soviet writer only if he/she belonged to the Writers' Union, the only official organization of writers. However, a membership in this creative union was unattainable for politically unreliable people (such as Tomas Venclova, who failed to join the Writers' Union in 1971) ${ }^{6}$.

The collections of the Soviet writers' autobiographies were getting thicker with each new publication. In each new edition, the living authors were able to include an old, updated or completely new version of their autobiography. The autobiographies of the dead writers would be reprinted, thus creating a paradoxical coexistence of the Stalin-era autobiographies ridden with the formulas of the old days along with the autobiographies written later, in the $9^{\text {th }}$ decade of the $20^{\text {th }}$ century when it was no longer necessary not only to adapt to the requirements of ideology, but also to adhere to the framework of the autobiography genre.

In the 1957 edition of the autobiographies, there were 13\% written by women, in the 1967 edition, $12 \%$, in the 1977 edition, 13\% and in the 1989 edition, 14\% were written by women writers. The share of women's autobiographies increased slowly just as their membership in the Writers' Union.

Silenced, semi-told, told

As French scientist Marie-Françoise-Chanfrault Duchet points out, “The autobiographical process uses not only facts and events, but also social representations and cultural values"7. In other words, the autobiography reveals not only the individual, but also the times in which one lives. It is also important to note that the term “Soviet Lithuanian writers” expresses a very different content. The collections include autobiographies of writers, who lived

5 Tarybinių lietuvių rašytojų autobiografijos (Autobiographies of Soviet Lithuanian writers), Vol. 1-2, A-C, L-Z, ed. Aldona Mickienè, Vaga, Vilnius 1989.

6 Donata Mitaitė, Tomas Venclova. Speaking Through Signs, transl. Diana Bartkutė-Barnard, Lietuvių literatūros ir taustosakos institutas, Vilnius 2002, p. 100.

7 Marie-Françoise Chanfrault-Duchet, Textualisation of the Self And Gender Identity in the Life-Story. In: Feminism and Autobiography: Texts, Theories, Methods, ed. Tess Cosslett, Celia Lury and Penny Summerfield, Routledge, London-New York: 2000, p. 61. 
in quite different times, i.e., some authors were already dead, while others were not yet born. It is also obvious that different generations view the autobiography from different angles: the older writers feel obligated to tell about their parents, childhood, education, etc., whereas the younger authors limit themselves to general observations on writing. For instance, Dalia Saukaityte (b. 1950) provides a five-line reasoning as to the goals of the autobiography, an eight-line poem and adds, "As an exception, I propose to associate the lyrical subject with

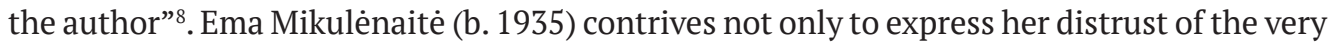
genre ("the more I like the author, the less I want to know about him") ${ }^{9}$, but also to ridicule the plan that used to be one of the cornerstone concept of the Soviet society and economy:

So I write only at the request of the publishing house which has its own plan [...]. And that plan from the times of my schoolday essays has always seemed to be some kind of an implacable mythological creature who even now has no problem throwing backhandedly at you your manuscript which, by the way, contains your truest autobiography... ${ }^{10}$

The inclusion of Lazdynų Pelèda (pen name of Marija Ivanauskaitė-Lastauskienè, 18721957) among Soviet writers is paradoxical since she comes from the literature of the end of the $19^{\text {th }}$ and the beginning of the $20^{\text {th }}$ century and did not write anything during the Soviet times because of her old age. In her 1954 autobiography (the year that the first volume of her writings appeared and wherein this autobiography was published for the first time), she gave a broad description of the $19^{\text {th }}$ century landowners' life to come: her newly-wed parents are expecting a heir to their name and estate, but instead two girls are born (both later in life became writers). The parents are unhappy until finally a boy is born. She also tells her grievance in detail how she never received a formal education due to her parents old-fashioned views. In general, Marija Lastauskienè-Lazdynų Pelèda tells all about her life and only at the end she hints to her writing. She concludes her autobiography with the following summary, "I am provided for in my old age. [...] My daughters have already gotten quite a bit of grey in their hair. My grandchildren and great-grandchildren are growing up and the doors to education are wide open for them"11. The last sentences sounds like an expression of gratitude for the Soviet government, which was characteristic of the Stalin era, but it also voices her opinion formed by the life experience: she sincerely lamented her lack of education, she

\footnotetext{
8 Tarybinių lietuvių rašytojų autobiografijos, Vol. 2, 1989, p. 517.

9 Ibidem, p. 242.

10 Ibidem.

11 Ibidem, p. 79.
} 
reached adulthood during the times of active fights for women's rights and in her writing she defended women's autonomy. While reading the texts of the first Soviet decades, one should be familiar with the rules of the epoch and the destiny of a certain individual. For example, Ona Miciūtè (1909-1973) in her 1951 autobiography concludes:

I left the Academy of Sciences [...] in July of 1950 [...] In 1941, I was married to Ivan Sútov of Belarusian nationality. In November of 1944, he was arrested and evacuated to Belarus. In 1950, I severed all ties with him. My family does not have anybody who has been arrested, evacuated or fled to the West ${ }^{12}$.

We learn from other sources that Miciūtė was accused of "burning two candles" in 1950 and was thrown out from the Writers' Union, which also meant that she was no longer able to do any literature related work. Realising that she will be fired anyway, she left ("retired") the Institute of the Lithuanian Language and Literature. Since the concept of an enemy of the people was applicable to family members and relatives, it was necessary to publicly denounce the enemy. It was a crime to have any relatives who escaped to the West. "Evacuation" really meant that Miciūtè's husband was arrested and imprisoned. After being ousted from the literary life, Miciūtè kept a diary in which she poured out the bitter truth about the Soviet occupation. This is one of the most dramatic autobiographies that was told in half-whisper. Tatjana Rostovaitè (1926-1993) stands out in the context of those who knew what was expected from the Soviet female writers:

More than fifteen years ago, I became a "living widow" and raised my kids alone. The then chairman of the Writers' Union Alf. Bieliauskas helped me get a small apartment where for the first time I was able to have my own office ${ }^{13}$.

She got her previous "good apartment in Žvėrynas district” thanks to "A. Venclova's ${ }^{14}$ initiative”. Apartment distribution was one of the routine functions of the Writers' Union so there should have been no place for personal favors. But here was a middle-aged woman feeling grateful as if the chairman in person helped her more than others in the procurement of her apartment. However, there are no instances of gratitude for the provided material goods, including apartments, expressed in the autobiographies of the male writers, but women still

\footnotetext{
12 Ibidem, p. 210.

13 Ibidem, p. 481.

14 Antanas Venclova (1906-1971) - writer and Soviet public figure, father of writer Tomas Venclova.
} 
need assistance and still feel grateful to high ranking officials for their help with domestic matters as well as for their encouragement to write. Rostovaitè touches upon many essential problems that the Soviet writers were faced with (for instance, she regrets that "the post-war restrictions" suppressed intimate poetry and did not allow a more personal expression in civil poems (it was dominated by “cold, official rhetoric") ${ }^{15}$, and also mentions her children, "I had a son and two daughters. I even felt happy quite often, especially when the kids were not sick" ${ }^{16}$. However, the fact that Rostovaitè talks about her children being sick and later on lists their illnesses in detail most likely serves as her alibi providing her the right to talk "incorrectly" and to digress to her personal life:

[...] around 1980 my both eyes developed cataracts, and then because of a severe mental trauma I suffered a mini stroke which led to cerebral circulatory insufficiency. After that, I had to get treatment twice a year as an outpatient and in hospital. Even more so when my heart started failing as well ${ }^{17}$.

Sofija Čiurlionienè-Kymantaitè ${ }^{18}$ also mentions her health problems in her autobiography dated 1957, just a year before her death ("Severe hypertension made me quite unfit for work [...] Depression, hypertension's escort, left me completely helpless” ${ }^{19}$ ), but it is likely that the author seeks to justify why she writes so little (a Soviet writer had to be productive). Bronè Buivydaite also complains about her poor eyesight but at the same time appreciates that she still has wonderful memory ${ }^{20}$. Shortly thereafter, Buivydaite became totally blind. The most likely conclusion is that Soviet writers could talk about their body only while describing their health problems: old women, who were no longer sexual objects, seemed to have gained their bodies back even though they were ailing and interfering with their work. Young women mentioned their illnesses only as an extension of their unhappiness ("material hardship, deteriorating health" ${ }^{21}$ ) without going into further details.

\footnotetext{
15 Tarybinių lietuvių rašytojų autobiografijos, Vol. 2, p. 478.

16 Ibidem, p. 479.

17 Ibidem, p. 482.

18 Sofija Čiurlionienè-Kymantaitè (1886-1958) was a well-educated academic and a diplomat. Realizing the value of M.K. Čiurlionis's heritage, she made sure his works of art were transferred to Lithuania, and led by her cultural ambitions she embodied an independent woman - an intellectual, dignified widow, a hostess of riveting intellectual discussions at her home in the interwar period.

19 Tarybinių lietuvių rašytojų autobiografijos, Vol. 1, p. 279.

20 Ibidem, p. 195.

21 Vidmantė Jasukaitytė (b. 1948), ibidem, p. 546.
} 
Younger women writers almost never talk about their adult private lives, or if they do, they talk in general terms (Jasukaitytè), although they do speak about their geneology and childhood extensively. Here is how poet Judita Vaičiūnaitè starts her autobiography:

With time passing by, I want to understand myself better (then I will be able to understand others better, too). I want to further understand my roots, to perceive myself as a particle of the society, connecting past and future generations ${ }^{22}$.

The rest of the story talks about her father, grandparents, their birthplaces, i.e., mostly about the things that occurred prior to Vaičiunaitè's birth or in her childhood, the facts she heard about from her relatives, mostly her mother (although the exact source of information is not disclosed). The following detail, although not necessarily true, is important to the psychological portrait:

I know that father, who never had kids in his first marriage, really wanted them. So it seems to me that he really longed for $\mathrm{me}^{23}$.

A person, especially a child, draws a sense of psychological security from the fact that he or she was longed for. Later on, this story, along with other ones, was included into her prose $^{24}$. However, Vaičiūnaite essentially refuses to write her own autobiography and concludes her writing with:

And my own autobiography? Perhaps it's in poems, as much as I was able to express it, as much as the words allowed me to ${ }^{25}$.

In contrast to the Vaičiūnas's family legend about expecting a child, there is Marija Lastauskienè's account (also based on a family legend) about the unwanted girls born to their parents: "Young parents were disappointed: instead of the expected heir they got a girl" (in reference to Sofija's birth); and later “again another newborn, but, alas, not the expected

\footnotetext{
22 Ibidem, Vol. 2, p. 707.

23 Ibidem.

24 Judita Vaičiūnaitè, Mabre viešbutis. Memuariné proza [Hotel Mabre. Memoires in Prose], Lietuvos rašytojų sąjungos leidykla, Vilnius 2009.

25 Tarybinių lietuvių rašytojų autobiografijos, Vol. 2, p. 709.
} 
heir, only a girl, useless and unwanted, skinny and small” (Marija) ${ }^{26}$. It is possible to state that family tales are used to form a child's perspective of themselves and their status.

At the first look, it appears to be a paradox that younger writers, while not going into detail about their marriages, would often mention their divorces and the divorce would be understood as an essential change, transgression after which women find themselves as social outcasts. The most prominent short-story writer of the period Bitė Vilimaitè (1943-2014).

Love stories are never mentioned unless they result in marriages. These marriages are portrayed as a drama, filled with (material) poverty and raising children. In this respect, Vidmantė Jasukaitytė's account is the most thorough:

I did not finish my studies... My marriage was a failure. I started living in dorms and apartments... At the time when my moral was at its lowest, I remember this incredible thirst for poetry - everywhere [...] These years resulted in my first book of poetry [...] and son Kęstutis. [...] My writing and my son were my saviors ${ }^{27}$.

While writing about her father, Jasukaitytė repeats the word "disagreement" a few times ("Fighting at home, disagreements over trifle matters"; "the family disagreements were too hard on the child who was longing for beauty and love" $)^{28}$, whereas Janina Degutyte (1928-1990) only mentions that during the war she lost "all three who loved her and she loved them" ${ }^{29}$ and also tells that her mother "was in need of her help" but does not provide a detailed descipion of her life. Degutyte's autobiography depicts last year of her life was never completed ${ }^{30}$. It is the most horrifying documentary text that reveals a young girl's life with her alcoholic and sadistic mother in the fourth decade of the 20th century Kaunas. Obviously, such childhood was “inappropriate” for a Soviet writer's autobiography (during and right after the war, her home became a brothel) and the writer herself was a particularly private person. It is obvious that an autobiography written for the autobiography collection of Soviet writers is in general not meant for scriptotherapy. However, due to these concealments some of the texts become hard to understand. For instance, only from additional

\footnotetext{
26 Ibidem, p. 35-40.

27 Ibidem, Vol. 1, p. 546.

28 Ibidem, Vol. 1, p. 544-545.

29 Ibidem, Vol. 1, p. 310.

30 Nebaigta autobiografija (Incopleted autobiography). In: Janina Degutytė, Atsakymai (Answers), Regnum fondas, Vilnius 1996.
} 
sources that became available after 1990 it is possible to understand what Violeta Palčinskaitè (born in 1943) talks about:

I was born in Kaunas, in the midst of the war. I had no right to be born because my mother was hiding the Nazis, and each of my cries could have ended in the entire family getting killed. Thus, I spent my first year of my life in a chest wherein my grandmother used to keep the linens ${ }^{31}$.

There is no mention in the text as to why the mother was hiding. The reader can only guess that she was a Jew. Although there were no openly anti-Jewish campaigns during the late Soviet period, the officials did not like even their name (the Holocaust was referred to as the killing of the Soviet citizens, and so on). Palčinskaitè revealed her mother's nationality after 1990. Similarly, Dalija Epšteinaitè-Kyjv wrote about her family that "they would speak in Russian, Lithuanian and Yiddish, and some French was heard as well because her parents had spent their youth in France" (in the author's opinion this partly determined her interest in "the translation process") ${ }^{32}$. Since there were very few foreigners who spoke Yiddish, one can guess that the author grew up in a Jewish family. Although the Jewish tragedy was not a topic often discussed in public, it became deeply engraved on the memories of many Lithuanians.

The families that future writers grew up in could be intellectual, but not rich. Only the translator Ona Doveikienè (born in 1920) mentions attending “a French kindergarten, a German elementary school and a Lithuanian gymnasium”33, but her autobiography was written in 1985 when there was no longer a need to prove an appropriate social upbringing. The level of ideological engagement, as mentioned before, partly depended on when an autobiography was written. However, it would be incorrect to summarize that later times always meant fewer ideological clichés. There are cases of voluntary demagoguery: certainly nothing would have happened to the writers if in 1985 they had written a different text. I quote:

I was born into a large family of a furniture maker and my roots reach deep down to the most revolutionary class of the workers [...] The Soviet years were the start of my happy childhood: I was one of the first in our town to put on a bright pioneer kerchief on my

\footnotetext{
31 Ibidem, Vol. 2, p. 335.

32 Ibidem, Vol. 1, p. 345.

33 Ibidem, Vol. 1, p. 103.
} 
chest. [...] My further life only deepened my communist ideological convictions and allowed them to thrive in my heart and soul ${ }^{34}$.

Despite a few bright spots, women's view of their own writing is excessively modest and non-competitive ("I did not seek to break the »ceiling " of literature, to rise high, to surpass, to conquer...”, as Elena Meziginaite wrote). In other words, since the Soviet female writers were a minority living in a patriarchal society, they represented themselves according to the norms.

\section{In Conclusion}

Those who try to understand the Soviet times first are faced with a question what sources to rely upon and how to interpret them from the standpoint of "a truth" and "a non-truth". Consequently, a growing interest in documentaries and semi-documentaries is natural: a person telling his or her life experience finds it important to prove his or her uniqueness by using even the limited resources that were available to Soviet women writers. On the other hand, in the $20^{\text {th }}$ century, the longing for "authenticity" engulfed even those societies that did not experience such obvious censorship. In the introduction to the collection of articles about autobiographies, Robert Folkenflik cites his undergraduate: "When I read a bad novel, I wind up with nothing; but when I read a bad autobiography I still have something" ${ }^{35}$. By definition, an autobiography should be an intimate, even confessional writing. The situation is complicated by the fact that the autobiographies were written specifically for an autobiographic collection or on some other professional occasion, i.e., it was understood that a public persona was expected to dominate the text. The autobiographies that appeared out of this tension share a number of commonalities determined by the same timeframe and common socio-cultural environment (after all, during the Soviet times writers used to live next to each other). From the perspective of the $21^{\text {st }}$ century, the private part of writers' life is shown with restraint and dropping hints in the hope that the reader will be able to decipher them, just like in fiction. However, the biggest surprise after reading the volumes of autobiographies of Soviet writers arises from a realization that, despite the omissions and formal reasons of these collections, they contain quite unique testimonies of their lives.

Translated by Vilma Kurapkaitè-Berg

\footnotetext{
34 Ibidem, Vol. 2, p. 652-655.

35 Robert Folkenflik, Introduction: The Institution of Autobiography. In: The Culture of Autobiography: Constructions of Self-Representation, ed. Robert Folkenflik, Stanford University Press, Stanford, California 1993, p. 11.
} 


\section{Bibliography}

Benstok Shari, Authorizing the Autobiographical. In: The Private Self: Theory and Practice of Women's Autobiographical Writings, ed. Shari Benstok, Routledge, London 1988.

Chanfrault-Duchet Marie-Françoise, Textualisation of the Self and Gender Identity in the Life-Story. In: Feminism and Autobiography: Texts, Theories, Methods, ed. Tess Cosslett, Celia Lury and Penny Summerfield, Routledge, London-New York 2000.

Degutytė Janina, Nebaigta autobiografija. In: Atsakymai, Regnum fondas, Vilnius 1996.

Folkenflik Robert, Introduction: The Institution of Autobiography. In: The Culture of Autobiography: Constructions of Self-Representation, ed. Robert Folkenflik, Stanford University Press, Stanford, California 1993.

Leinartė Dalia, Adopting and Remembering Soviet Reality: Life Stories of Lithuanian Women, 19451970, Rodopi, Amsterdam 2010.

Lejeune Philippe, The Autobiographical Contract. In: French Literary Theory Today: A Reader, ed. Tzvetan Todorov, transl. R. Carter, Cambridge University Press, Cambridge 1982, p. 193, internet access: https://english4321.files.wordpress.com/2010/08/philippe-lejeune-the-autobiographical-contract.pdf.

Mitaitė Donata, Tomas Venclova. Speaking Through Signs, transl. Diana Bartkutė-Barnard, Lietuvių literatūros ir taustosakos institutas, Vilnius 2002.

Tarybinių lietuvių rašytojų autobiografijos, Vol. 1, A-K; Vol. 2, L-Ž, ed. Aldona Mickienė, Vaga, Vilnius 1989.

Vaičiūnaitė Judita, Mabre viešbutis. Memuarinė proza, Lietuvos rašytojų sąjungos leidykla, Vilnius 2009. 


\section{Życie prywatne $i$ publiczne w autobiografiach pisarek litewskich}

\section{Streszczenie}

Materiał badawczy niniejszego artykułu został zaczerpnięty z biografii litewskich pisarek, opracowanych i zebranych w publikacji Tarybinių Lietuvos rašytojų auobiografijos [Autobiografie pisarek radziecko-litewskich t. 1-2, red. Aldona Mickienè, Wilno 1989]. W artykule zwrócono uwagę na to, co, zdaniem pisarek, należało mówić o sobie i co - na podstawie tej narracji - można sądzić o standardach społecznych narzucanych kobietom. Pisarki były częścią patriarchalnego, normatywnego społeczeństwa, w którym ich rola była drugorzędna. Pragnąc dorównać mężczyznom, starały się kłaść nacisk na swoje życie zawodowe, dlatego dominującym tematem ich autobiografii jest działalność społeczna. Z drugiej strony autobiografia, jako gatunek marginalny, stanowiła wygodny pretekst do wyrażenia osobistych przekonań, co w innych gatunkach literackich nie było wówczas możliwe. Celem artykułu jest ukazanie złożonego związku pomiędzy indywidualnymi cechami osobowościowymi i specyfiką życia w czasach sowieckich. Autobiografie stanowią zarówno bogate źródło badań pisarstwa kobiecego, jak i studium dokumentalistyki społeczeństwa w czasach sowieckich.

\section{Słowa kluczowe}

literatura drugiej połowy XX wieku, pisarki, autobiografie pisarzy, autobiografia kobieca

Przełożyła na język polski Imelda Vedrickaité-Frukacz

PROSIMY O CYTOWANIE TEGO ARTYKUŁU JAKO:

Solveiga Daugirdaitè, Private and professional life in autobiographies of Lithuanian women writers, „Autobiografia. Literatura. Kultura. Media” 2015, nr 1 (4), s. 61-72. 